\title{
DETECTION OF FORMER LANDFILLS IN GRAVEL PLAIN USING GEOMORPHOMETRIC ANALYSIS AND HIGH-RESOLUTION LIDAR DTM
}

ODKRIVANJE PRIKRITIH ODLAGALIŠČ ODPADKOV V PRODNI RAVNINI

Z GEOMORFOMETRICNO ANALIZO IN LIDAR DMR

Mateja Breg Valjavec

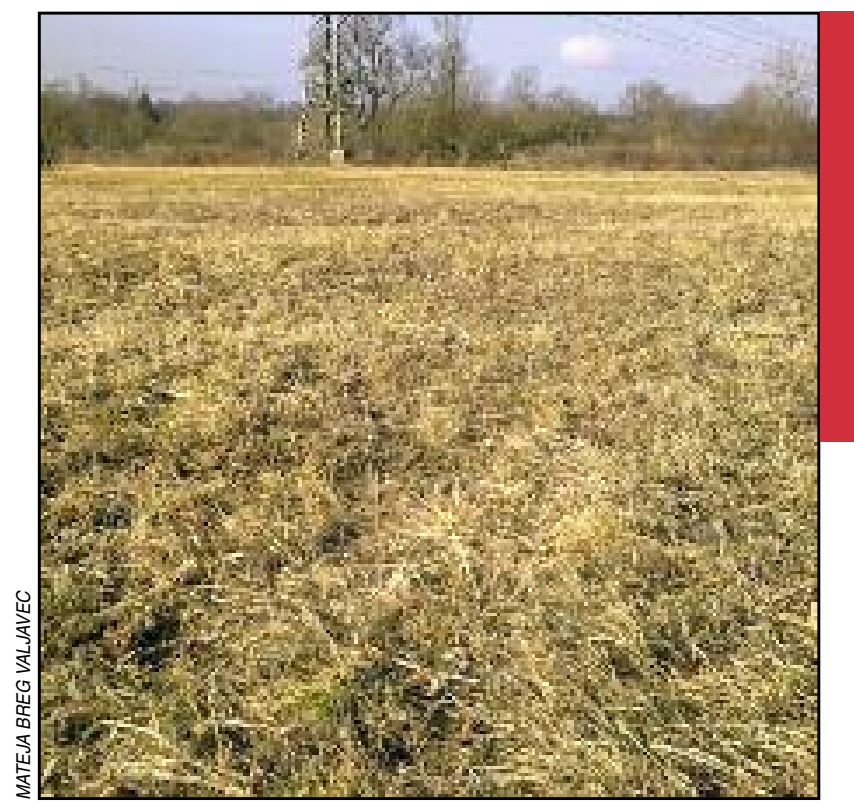

Bumpy and wavy micro-terrain of former landfill in Ljubljana gravel plain. Grbinast in valovit mikro-relief nekdanjega odlagališča odpadkov na Ljubljanskem polju 


\title{
Detection of former landfills in gravel plain using geomorphometric analysis and High-Resolution LiDAR DTM
}

\author{
DOI: http://dx.doi.org/10.3986/AGS54106 \\ UDC: $911.2: 551.43(497.451 \mathrm{Lj}$. polje) \\ 551.43:628.472.3(497.451Lj. polje) \\ 628.472.3:528.8(497.451Lj. polje)
}

COBISS: 1.01

\begin{abstract}
The article represents the application of geomorphologic approach to discover the potential areas of buried waste in agricultural landscape of Ljubljana gravel plain. Some former waste disposal sites or landfills are underground sites characterized by heterogeneous old waste buried in formerly concave landforms: old inactive gravel pits or paleo-riverbeds. They form different types of anthropogenic landforms. They were primary recognized and located with the terrain visualization (analytical shading, hypsometry) of LiDAR data and in continuation with geomorphometric analysis and classification of fluvial terrain. Due to subsidence of heterogeneous waste, terrain of former landfill sites is bumpy and uncharacteristic of fluvial surface morfology or terrain. The geomorphometric analysis was applied to differentiate the anthropogenic landforms (gravel pits, filled gravel pits ...) from natural alluvial landforms with combination of two geomorphometrics: multiresolution index of valley bottom flatness $(\mathrm{MrVBF})$ and convergence index and high density LiDAR data. Result is the automatically derived classification of terrain in to three classes: (1) bumpy terrain, typical for areas with high terrain potential for landfill, (2) flat terrain, typical for dry paleo riverbeds and (3) »agricultural « terrain, typical for intensive fields and meadows. By comparing the results of geomorphometric analysis with the results of visual analysis the 26 of 46 visually detected anthropogenic landforms are overlapping the areas of high terrain potential for landfill and among these 8 objects were proved with geohistorical analysis of archive aerial photographs.
\end{abstract}

KEY WORDS: applied geography, landfill, gravel pit, paleo riverbed, visualisation technics, geomorphometry, LiDAR, DTM, Ljubljana gravel plain.

The article was submitted for publication on January 14, 2013.

\section{ADDRESS:}

Mateja Breg Valjavec, Ph. D.

Anton Melik geographical Institute

Research centre of Slovenian academy of sciences and arts

Novi trg 2, SI - 1000 Ljubljana, Slovenija

E-mail: mateja.breg@zrc-sazu.si 


\section{Introduction}

The main research objects are former landfills on Ljubljana gravel plain. These are underground objects characterized with heterogenous old waste being buried in once concave landforms. The results of previous Slovene studies (Bricelj 1988; Šebenik 1994; Kušar 2001; Breg and Urbanc 2005; Breg et al 2007; Smrekar 2007 etc.) and some international studies (Silvestri in Omri 2008) showed that in the past the waste was often illegally disposed in natural (paleo river beds, sinkholes) or anthropogenic basins (gravel pits or other open mining pits). Regarding these the research is oriented in study of landfills in gravel pits and paleo riverbeds being among the most frequent concave landforms in the terrain of Ljubljana gravel plain.

The main objective of this research is to show that landfills can be determined also by using geomorphic methods and LiDAR terrain data. Despite the remarkable accuracy and usefulness of LiDAR data can be theoretically determined only landfills, the consequences of which are visible in the LiDAR DTM, which applies to landfills that were not adequately covered with a thick layer of fertile soil, which would allow intensive farming. At these landfills intensive agricultural land use and production is not present, but meadows and reforestation, which is reflected in the micro-terrain and in texture of shaded terrain.

Many researchers attempted to identify buried waste by using various techniques of remote sensing and multispectral satellite data. They were focusing on degraded vegetation and soil pollution. Detailed review of past remote sensing researches is available in Silvestri and Omri (2008), Slonecker et al (2010) and others. Almost none research has been done in terms of studying the effects on geomorphology resulting from the landfilling of waste. Using Landsat TM and ETM satellite data or very higher spatial resolution remote sensing data (Quickbird, Ikonos, GeoEye1) also geomorphic changes in various geomorphic features, such as riverbed and shoreline migration, meanders and old riverbeds can be identified (Ghanavati et al. 2008). Podobnikar et al. (2008) showed that analysing DTMs with $25 \mathrm{~m}$ pixel resolution enables highlighting changes to the geomorphology and makes human impacts visible as they clearly noticed many anthropogenic landforms (road embankments, traffic infrastructure, filled sinkholes, active gravel pits) on a karstic surface also with marking the differences between DTMs from different periods. By photogrammetric processing of the archive aerial photographs DTM of former landscape can be processed. By further comparison with DTM of recent landscape elevation differences may be calculated. Using this approach the number and extent of filled dolines was quantitatively analysed in Slovene Logatec karst polje (Breg Valjavec 2010). For the Bílina coal mine (Slovak Republic) the elevation data was obtained for different periods and volumetric analysis was used to calculate the temporal terrain differences (volume of excavated minerals) completed during the selected years (Pacina and Weiss 2011).

The research is focusing in smaller landfills that are able to be visualized on the LiDAR terrain and recognized as the anthropogenic landforms through discovering the terrain texture of »scars« that were created in landscape due to underground waste dumping. The idea to recognize landfills with geomorphometric analysis of recent terrain became more realistic with the availability of high-density LiDAR data, development of digital geomorphometric methods and specific software. DTM, which is obtained from a laser cloud of points, reflecting even the smallest variation in the topography (from few centimeter to some ten's centimeters), being a consequence of geomorphological and anthropogenous processes (Mlekuž 2010), like the land use impacts in terrain. LiDAR allows observation traces, scars and finger prints of natural and anthropogenic processes on the Earth's surface (Komac 2009; Mlekuž 2010).

\section{Case study area}

Ljubljana plain in general represents a tectonic depression filled mainly with gravel and sand sediments. In fluvial terrain of the gravel plain several terraces (highest Pleistocene and the lower Holocene terraces) accompany the main River Sava (Radinja 1951; Šifrer 1969). By moving river current from old into new riverbed paleo riverbeds have formed. In the recent landscape these are longitudinal slightly concave landforms that can be identified as lowering's in terrain, especially in the lower Holocene terraces. Regarding this the study area was narrowed down to Holocene terrace. Study area (Figure 4) represents suburban belt (villages) on the northern part of Ljubljana that is interconnected with agricultural countryside (meadows and fields) and young forest vegetation along the River Sava. The areas in the immediate vicinity of cities were and are still impacted by illegal waste dumping (Breg and Urbanc 2005). Due to the gravel sediments, 
the wider area of Ljubljana plain has always been interesting for gravel extraction especially near Sava River. Many medium-size gravel pits (from 1,000 to 5,000 $\mathrm{m}^{2}$ ) were partially or completely filled with waste and turned into »waste pits« (Breg and Urbanc 2009).

\section{Methodology and LiDAR data}

The methodology is based on geomorphologic approach that determines landfill areas on the basis of fluvial terrain characteristics and determination of anthropogenic landforms. It consists of two recognition methods based on DTM data: (1) visualization technics (analytical shading and hypsometry) and (2) geomorphometric analysis. It is possible to determine the landform types with greater certainty with several different methods compared to each other (Ciglič and Gostinčar 2011). Numerical (geomorphometric) as well as visual analysis of DTM enables the recognition of landforms, such as ridges, picks, valleys (Podobnikar and Možina 2008) and also anthropogenic landforms. The anthropogenic landforms were primary recognized and located with the terrain visualization of LiDAR data and in continuation with geomorphometric analysis and classification of fluvial terrain.

The applied and analysed terrain data is LiDAR DTM (Lidar 2008, () GEOIN), based on data from laser scanning of 8 and 14 February 2008. Aerial survey was conducted by Optech Gemini LiDAR sensor. Primary data processing was done with Dashmap 5.3 and PosPac 4.4 software. For the final classification and treatment of the software package Terra Solid and MicroStation (Geoin 2011) was used. The cloud of points was divided into four classes of which we used class of points of the terrain. The terrain was smoothed by filling up the smaller »sinks « and analysed with visual and automated technics. Regarding land use types, only built up areas were excluded from geomorphometric analysis.

\section{Visual analysis and characteristics of anthropogenic terrain of landfills}

The Lidar DTM was visualized so the terrain anomalies of an anthropogenic origin were located in the terrain of recent landscape. Regardless of the wide spectre of its uses, it is important to demonstrate (visualize) the DTM effectively, as it is the only assurance to guarantee the appropriate result interpretation. Despite several descriptions of advanced terrain demonstration, analytical shading remains one of the most common methods (Zakšek et al. 2010). Analytical shading (Figure 2 and 3) simply means a computer-assisted assembly of a shaded terrain from the DTM. The method, developed by Yoëli (1965), where the value of the grey is in correlation to the cosine of the ray's incidence angle of the direct terrain lighting, has become the standard. This is the angle between the direction towards the light source and the perpendicular line to the terrain surface. In this way, the areas perpendicular to the ray from the imaginary light source are white, and the areas with an incidence angle of $90^{\circ}$ or more are in a complete shade or completely black, while the areas between an incidence angle between $0^{\circ}$ and $90^{\circ}$ are displayed with the appropriate grey or other color shade (Zakšek et al. 2010). The hypsometry (Figure 1) is a visualisation technic that allows us to adapt the image histogram to our needs and expose the smaller landforms and micro-terrain characteristics (landfills). Both visualisation technics, analytical shading and hypsometry, were applied separated on the same LiDAR data sections (measuring $750 \mathrm{~m} \times 500 \mathrm{~m}$ ). By selecting smaller sections of DTM also the interval among minimum and maximum elevation values has narrowed. Smaller sections of gravel plain enable better color contrast in visualising flat terrain at local scale and to detect micro-terrain variability and texture. With presented visualization methodology, we displayed DMR very precisely and reconstructed the old riverbeds in the agrarian landscape. We studied the natural terrain characteristics of fluvial terrain (paleo riverbeds) and anthropogenic landforms in order to determine geomorphic characteristics of landfills in filled basins.

The essential geomorphic characteristic of paleo riverbeds are very low slopes at the bottom of the riverbed (under $0.5^{\circ}$ ) that quickly increase (for a few degrees) on the fold to the slope. The terrain anomalies were identified in the riverbeds that are a consequence of human activity and are shown as a convex landform (embankment), which interrupts the riverbed flow on a certain section of the river and can then continue on once more (Figure 1). The quality of visual recognition of convex anthropogenic land- 


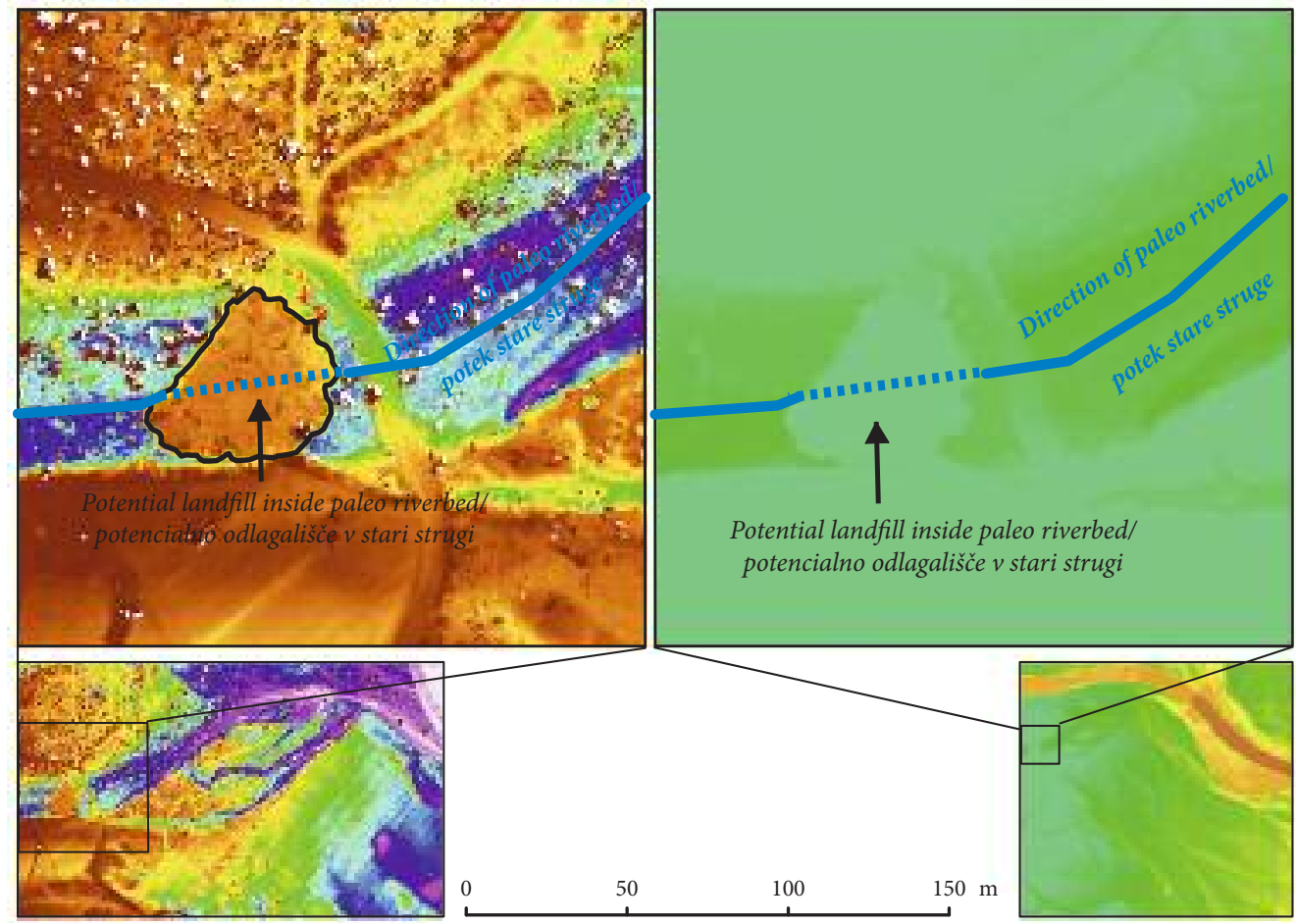

Figure 1: Reconstruction of paleo riverbeds with visual analysis of DTM in different scales and detection of geomorphic anomalies.

forms inside paleo riverbeds on LiDAR DTM depends on the size of study area. On the left image is taken zoomed view from visualization of $750 \times 750 \mathrm{~m}$ study area and on the right image is taken zoomed view from entire area.

Completely filled gravel pits do not particularly stand out in the terrain, as they were levelled with the surrounding terrain when they were filled. Since the waste may be very heterogeneous, it decays with different intensity. In accordance, a bumpy terrain is formed (Figure 2), which is untypical in the fluvial terrain of the alluvial plain. As the Latin name (Lat. Fluvio means river) designates, fluvial landforms are shaped by the movement of river water or in general when the laminar flow runs into a linear one due to its tendency to concentrate. For this reason, natural landforms in fluvial terrain are linear (valley, ravine, gorge, erosion channel and ridge).

Bumpy landforms, typical for filled gravel pits, can be successfully studied on shaded terrain as wavy texture (Figure 2). Natural fluvial terrain of studied agrarian landscape is changed also due to the traditional and intensive agricultural land use.

By analyzing high resolution LiDAR DTM the effects of different land-uses can be recognized. This enables the classification of different types of land use from the geomorphological point of view. In the case of filled gravel pits dumped waste represents anthropogenic bedrock.

In the formation of micro-terrain landforms in a completely flat terrain (gravel plain) play leading role landscape elements such as bedrock and in some cases also soil (soil depth), vegetation (tree roots), fauna (mole) and human. They can take the lead in geomorphological reshaping of flat terrain. Considering this, very similar bumpy micro-terrain was detected also in some other land use types:

- forest that is growing on the shallow soils (rendzina) on paleo-gravelbeds near Sava River;

- abandoned agricultural land inside extensive agrarian land, usually overgrown with bushes and trees, limited to the smaller strips or lots;

- traditional meadow or pasture that include trees (Figure 3, green ring). 


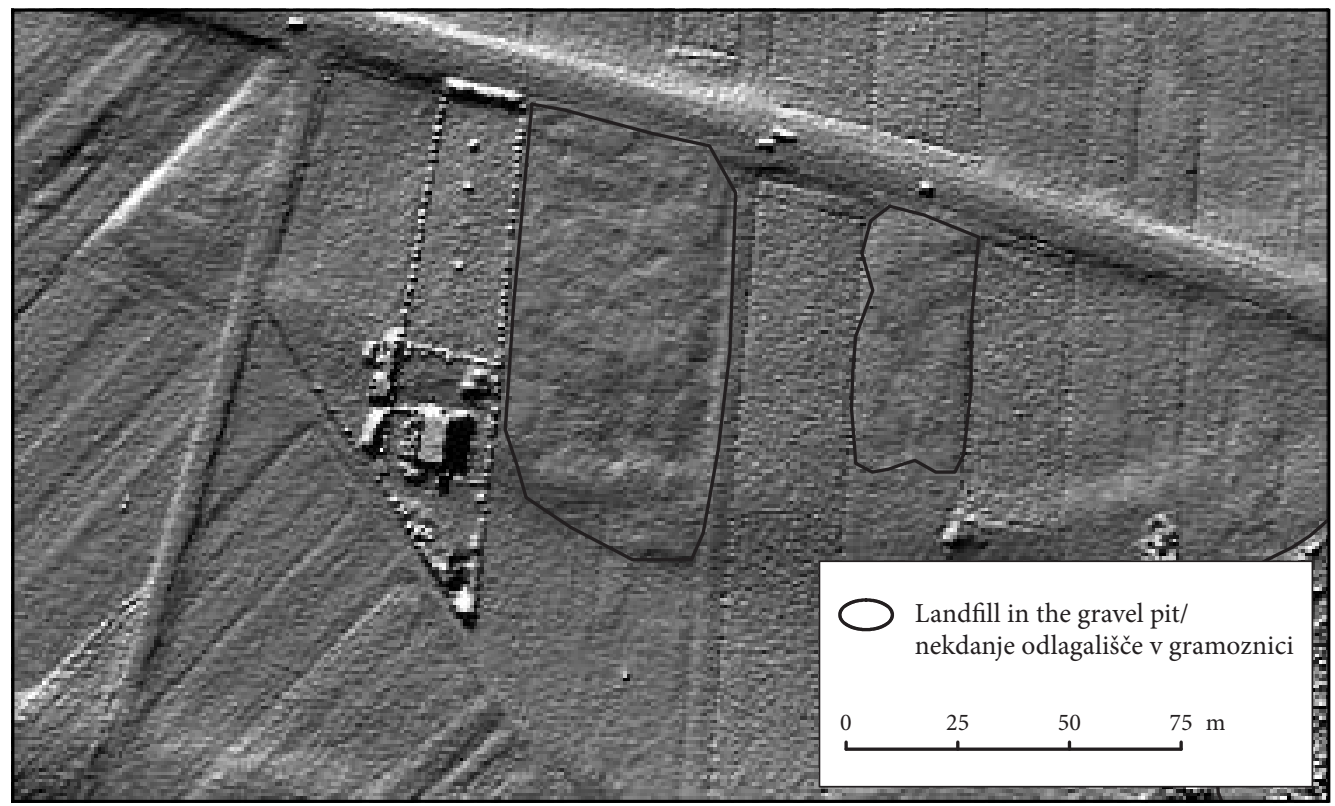

Figure 2: Terrain of filled gravel pit is usually slightly convex and bumpy (black ring area). The terrain of surrounding fields is agriculturally altered due to the plowing and tillage of soil.

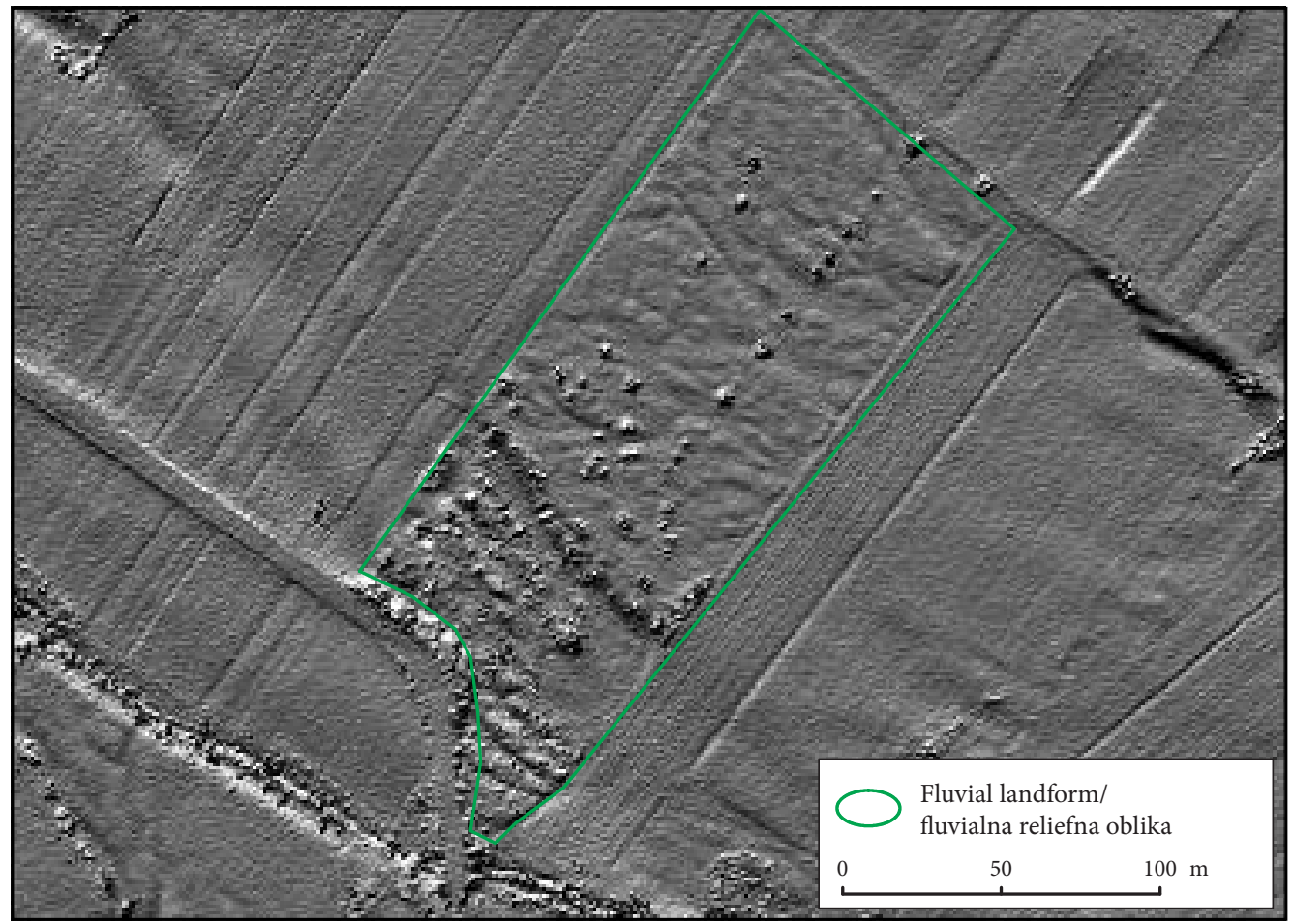

Figure 3: Micro-terrain that is shaped in traditional meadow (green ring) has very similar texture (micro-terrain) like the terrain of waste pit, used as a meadow (see Figure 2). 
Final dilema in separation between natural bumpy landforms and anthropogenic bumpy landforms (related to landfills) can be solved with geohistorical analysis of gravel pits, reconstruction of paleo riverbeds and field studies.

With the visual analysis of DTM the 67 potential anthropogenic landforms related to excavation of gravel and waste dumping (Figure 4) were defined on a $5 \mathrm{~km}^{2}$ of case study surface. Landforms were divided into four groups according to concavity / convexity, and potential for presence of buried waste (Figure 4):

1. Convex landforms are potential landfills if they are »overfilled « gravel pit or just a larger pile of dumped waste, expressly elevated above the surroundings.

2. Bumpy landforms (potential landfills):

2A. bumpy (slightly) convex micro-terrain,

2B. bumpy (slightly) concave micro-terrain,

3. Concave landforms are allegedly unfilled gravel pits or paleo riverbeds;

Considering further geomorphomorphic analysis only convex (5), bumpy convex (24) and bumpy concave landforms (17) are potential landfills. Regarding this we can conclude that 46 objects have potential to be landfill.

\section{Geomorphometric analysis and results}

Geomorphometry is the science of topographic quantification; its operational focus is the extraction of land-surface parameters (terrain) and objects from digital elevation models (Hengl and Reuter 2009, Hrvatin and Perko 2009) or digital terrain models. The modern geomorphometry differs from classical quantitative geomorphology while it's specialized on computer characterisation and analysis of continuous topography (Hengl and Reuter 2009). The geomorphometric analysis is a second phase of our research and encompasses determination of the potential areas that have the terrain characteristics typical for filled basins (landfills).

The DTM can be automatically divided into classes with the use of geomorphometric parameters (the slope, curvature, level of incline curves, topographic openness, the accumulation of the water current) in order to determine landforms connected to fluvial processes (Anders et al. 2009). The Convergence index was used to exclude the converging areas, as they are not typical for the area of filled gravel pits with bumpy terrain and may also represent natural concave landforms (paleo riverbeds) and unfilled gravel pits. The module (in SAGA software) calculates an index of convergence/divergence regarding to the overland flow. By its meaning, it is similar to a plan or horizontal curvature, but gives much smoother results. The calculation uses the aspects of surrounding cells, i.e. it looks to which degree the surrounding cells point to the center cell. The result is given as percentages; negative values correspond to convergent, positive to divergent flow conditions. Furthermore, the areas of the flattened terrain were separated from the not

Table 1: Joining the results of both geomorphometric indexes.

\begin{tabular}{lcccc}
\hline Layer number & Layer name & Cell value & Cell value & Layer 1+2 \\
\hline Layer 1 & $\begin{array}{c}\text { Index of convergence / } \\
\text { divergence }\end{array}$ & $\begin{array}{c}\text { (areas of converging, } \\
\text { draining) }\end{array}$ & 1 (areas of divergence) & CLASS 2 \\
Layer 2 & $\begin{array}{l}\text { multiresolution index } \\
\text { of valley bottom flatness }\end{array}$ & 0 (flat areas) & 1 (bumpy, wavy terrain) & $\begin{array}{c}1 \text { (flat but } \\
\text { anthropogenously } \\
\text { altered terrain) }\end{array}$ \\
\hline
\end{tabular}

Figure 4: Spatial distribution of anthropogenic landforms which were recognized and classified by visual analysis of LiDAR terrain on study area Ljubljana plain. > p. 28

Figure 5: Geomorphometric classification of alluvial terrain. > p. 29

Figure 6: Comparison of two terrain methods (visualisation and geomorphometric analysis) and further improvements of results with geo-historical analysis (Breg Valjavec, Gostinčar and Smrekar 2011). > p. 30 
Mateja Breg Valjavec, Detection of former landfills in gravel plain using geomorphometric analysis and High-Resolution LiDAR DTM

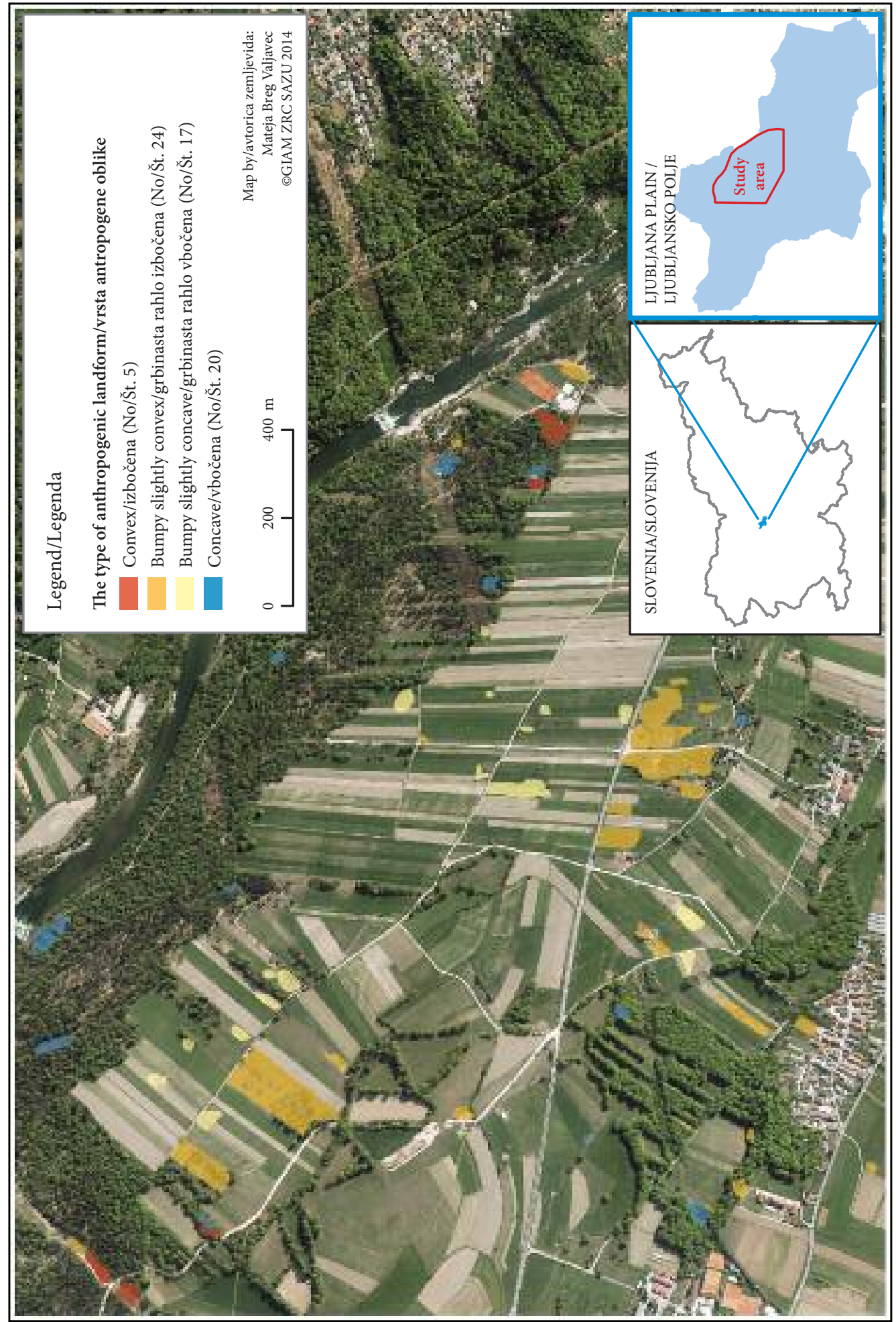




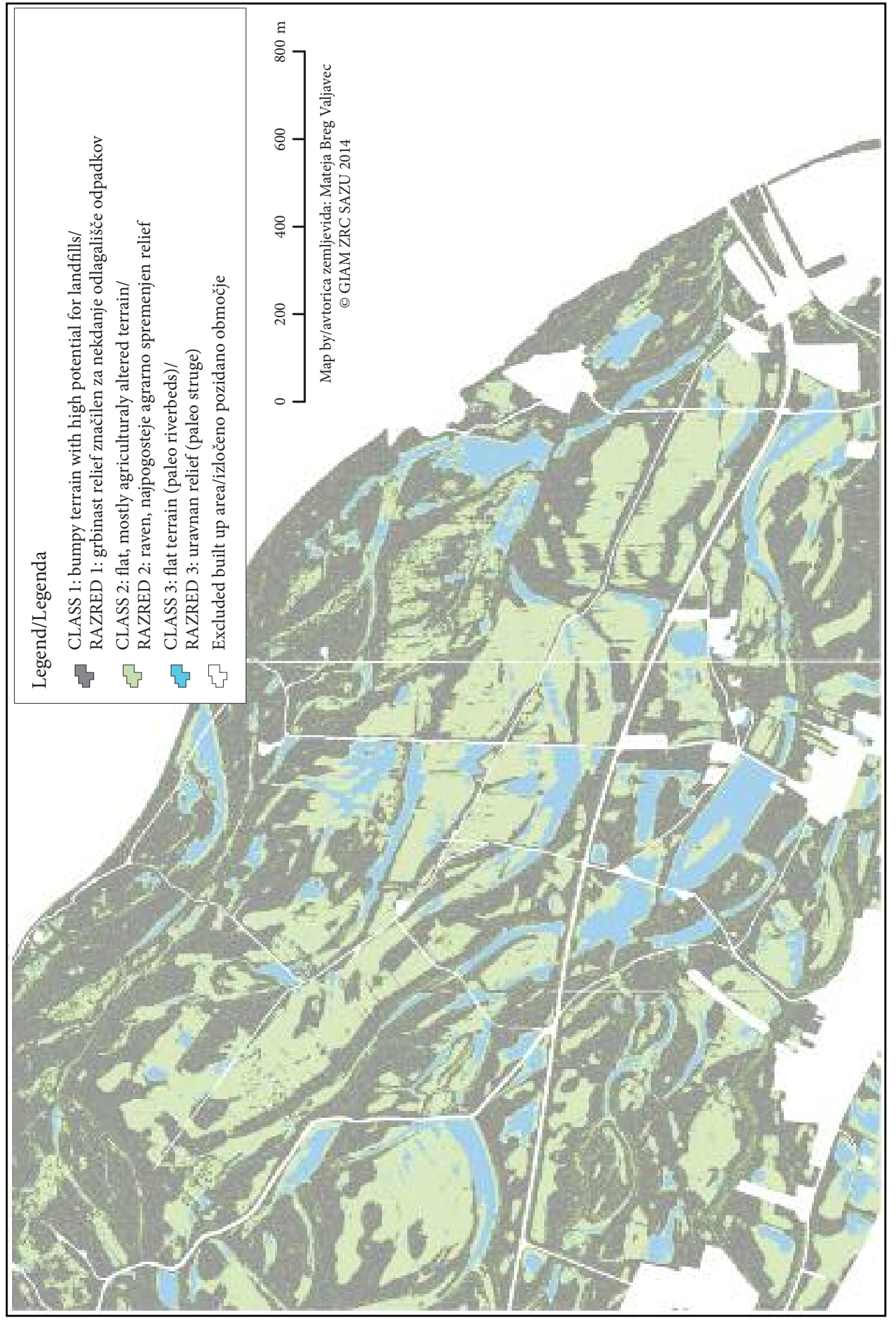




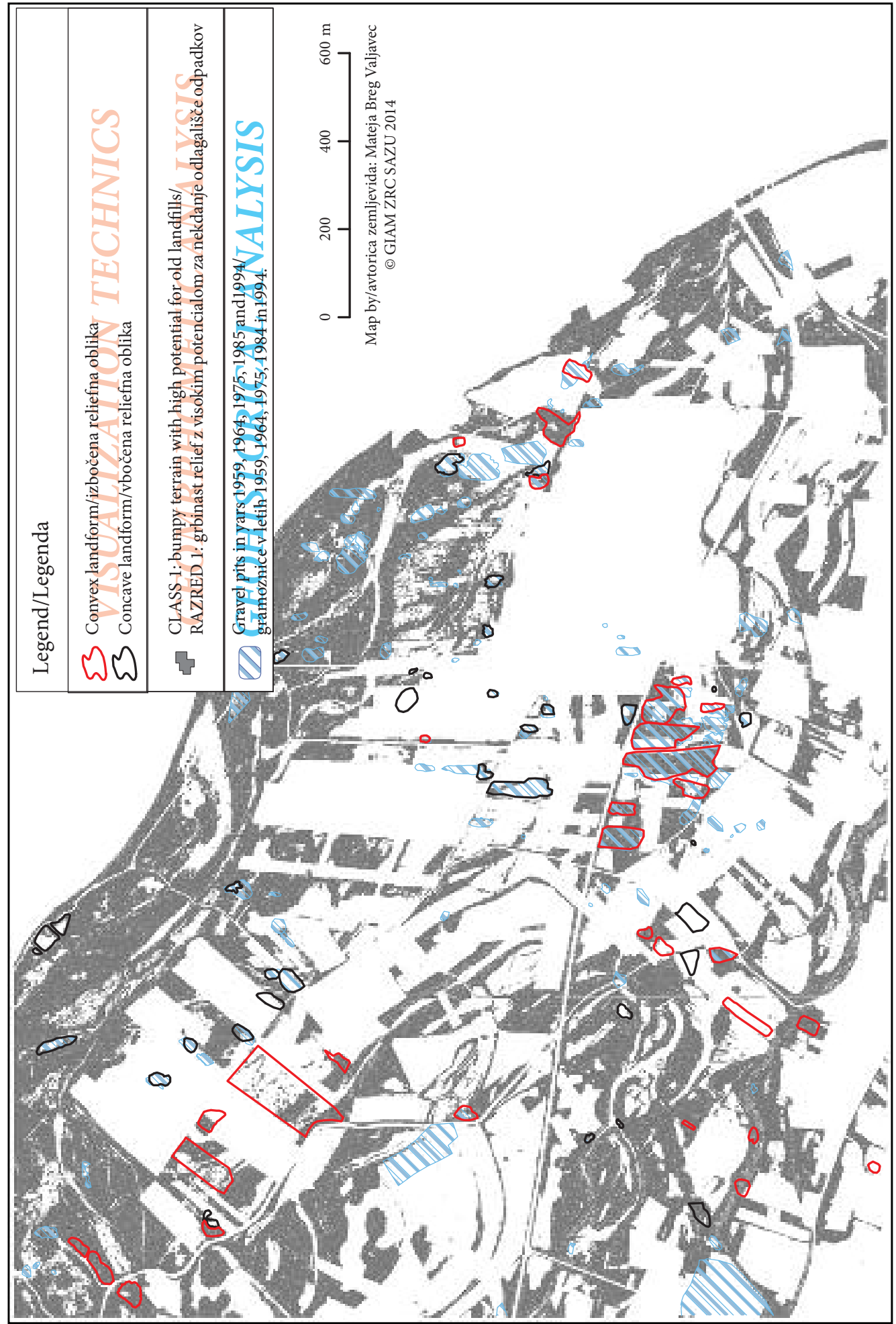


flattened one (wavy, bumpy) with a multiresolution index of valley bottom flatness (MrVBF module in SAGA software) intended for charting the sedimentation areas (in this case paleo riverbeds). The MrVBF algorithm (Gallant and Dowling 2003) works on raster DTMs. The Valley Flatness (VF) at a single scale is calculated as a function of (1) the local topographic position of a cell within a moving window and (2) the slope of a $3 \times 3$ cell window. A cell is part of a flat valley when it is locally low and has a low slope. Fuzzy VF values for multiple resolutions are calculated by resampling the DEM to increasingly coarse solutions and then repeating the procedure (Gallant in Dowling, 2003). Using the two described geomorphometric indexes (Layer 1, Layer 2) the alluvial terrain of study area was classified in to three classes (Table 1 and Figure 5). Class 3 is representing paleo riverbeds (completely flat areas) the areas inside Class 2 correspond to agriculturally altered areas that express flat terrain, similar to natural characteristics while Class 1 corresponds to areas of bumpy wavy terrain or terrain of landfills. The areas in Class 1 were named areas with a high terrain potential for landfills.

\section{Disscusion and conclusions}

By overlapping results from visual analysis (from Figure 4) with results of geomorphometric analysis (from Figure 5) 26 of 46 visually detected potential landfills are matching with the CLASS 1(the areas of high terrain potential for landfill, grey polylines in Figure 6). These 26 objects can be relatively surely characterized as landfills (red polygons). To improve the reliability of results, obtained from LiDAR analysis, we compared them (Figure 6) with geo-historical data on known locations of old gravel pits (Breg Valjavec, Gostinčar and Smrekar 2011). On the study area 30 gravel pits in different stage of excavation / degradation were registered from archive aerial photographs from years 1959, 1964, 1975, 1985 and 1994. Finally, only 8 locations were recognized with all three methods as the landfills.

Huge quantity and density data, which is obtained by LiDAR, is still the best managed and presented by visualization technics (Kalawsky 2009 in: Mlekuž 2010). Visualization technics are useful also at the local scale by studying smaller areas of flat landscapes. There are undoubtedly many options for determining landfills with the geomorphometric analysis of very precise LiDAR data in the future. The success in detection of landfills with geomorphometric analysis depends very much on the type of landfills, their micro-terrain characteristics and land use type above buried waste. The applied geomorphometric analysis is the suitable way for detection of convex and slightly convex bumpy objects that are potential landfills. On Figure 6 are represented as red polylines overlapping grey and grey-blue dashed areas. Concave and slightly concave landforms (on Figure 6 are represented as black polylines overlapping white areas) are converging areas representing either concave anthropogenic landforms (partially filled gravel pits, preserved gravel pits) or concave natural landforms and must be additionally studied with field survey in order to detect buried waste.

The method enables the best results on areas of agrarian land use (fields, intensive meadows) as well on open surfaces with no significant higher vegetation cover (no tress). In contrary, the methodology is almost not applicable for overgrowing areas inside agrarian land use and in forest as they express similar micro-terrain characteristics as waste pits. In order to improve results and to distinguish between natural and anthropogenic terrain in those land use types it is needed to study the vegetation cover (tree density and height). In addition some analysis of the ortho-photo images (i.e., infrared band) in combination with LiDAR vegetation layer can be performed. Regarding the field work on known landfills (Breg Valjavec 2012) we can assume that if the trees are tall and dense, it means they flourish on a stable natural rock foundation and natural soils that enable a stable growth to higher plants. Lower trees of bush growth inside forest may flourish on the areas of filled gravel pits, as the anthropogenic soils (deposols) and the inhomogeneous original foundation (waste) does not guarantee a static stability to the tall trees (e.g. English oak).

With future research the applied methodology should be improved in the framework of existing geomorphometric methods using GIS terrain modeling and additional data layers (land use data and near-infrared aerial photographs) as well as with more object oriented geomorphometric analysis. The presented geomorphometric analysis individually enables only detection of broader areas having terrain characteristics similar to landfills but not exactly the individual landfills object. Regarding the geomorphological backgrounds, on which the object oriented concept is based, the methodology could be applied in studying landfills in similar alluvial plains along rivers and can be put into the context of paleo riverbeds on floodplains. 


\section{References}

Anders, N., S., Seijmonsbergen, A., C., Bouten, W., 2009: Multi-scale and object-oriented image analysis of high-res LiDAR data for geomorphological mapping in Alpine Mountains. Proceedings of gemorphometry 2009. Zurich.

Breg, M., Urbanc, M., 2005: Gravel plains in urban areas: gravel pits as an element of degraded landscapes. Acta geographica Slovenica 45-2. DOI: http://dx.doi.org/10.3986/AGS45202

Breg, M., Urbanc, M., 2009: Skrite in odkrite gramoznice na Jarškem produ - odpadkovnice? Geografski obzornik 56-3.

Breg M., Kladnik D., Smrekar A., 2007: Dumping sites in the Ljubljansko polje water protection area, the primary source of Ljubljana's drinking water. Acta geographica Slovenica 47-1. DOI: http://dx.doi.org/ 10.3986/AGS47104

Breg Valjavec, M., 2010: Digitalni model višin nekdanje pokrajine - primer Logaško polje (leto 1972). Geografski informacijski sistemi v Sloveniji 2009-2010. Ljubljana.

Breg Valjavec, M., 2012: Geoinformatic methods for the detection of former waste disposal sites in karstic and nonkarstic regions (case study of dolines and gravelpits). Doctoral thesis, University of Nova Gorica, Graduate school. Internet: http://www.ung.si/člibrary/doktorati/krasoslovje/10BregValjavec.pdf (15. 10.2014).

Breg Valjavec, M., Gostinčar, P., Smrekar, A. 2012: Register virov onesnaževanja vodonosnikov Ljubljanskega polja in Barja. Geografski informacijski sistemi v Sloveniji 20011-2012. Ljubljana.

Bricelj, M., 1988: Popis odlagališč odpadkov in pokrajinsko-ekološki vidiki izbora

alternativnih lokacij za urejeno odlaganje smeti v občini Logatec. Ljubljana.

Bujána, S., González-Ferreiroa, E., Barreiro-Fernándeza, L., Santéa, I., Corbellea, E., Mirandaa, D., 2013: Classification of rural landscapes from low-density lidar data: is it theoretically possible? International journal of remote sensing 34-16. DOI: http://dx.doi.org/10.1080/01431161.2013.792230

Ciglič, R., Gostinčar, P., 2011: Primerjava rezultatov računalniškega prepoznavanja reliefnih oblik z rezultati geomorfološkega kartiranja. Geografski vestnik 83-1.

Gallant, J. C., Dowling, T. I., 2003: A multiresolution index of valley bottom flatness for mapping depositional areas. Water resources research 39. DOI: http://dx.doi.org/10.1029/2002WR001426

Geoin d. o. o. Geodetski inženiring Maribor, 2011: Laserski posnetek območja Kleče.

Ghanavati, E., Firouzabadi, P.Z., Jangi, A. A., Khosravi, S., 2008: Monitoring geomorphologic changes using Landsat TM and ETM+ data in the Hendijan River delta, southwest Iran. International journal of remote sensing 29, 3-4. DOI: http://dx.doi.org/10.1080/01431160701294679

Hengl, T., Reuter, H. I. 2009: Geomorphometry: concepts, software, applications. Amsterdam.

Hrvatin, M., Perko, D. 2009: Suitability of Hammond's method for determining landform units in Slovenia. Acta geographica Slovenica 49-2. DOI: http://dx.doi.org/10.3986/AGS49204

Komac, B. 2009: Social memory and geographical memory of natural disasters. Acta geographica Slovenica 49-1. DOI: http://dx.doi.org/10.3986/AGS51101.

Kušar, S., 2001: Metodologija ocenjevanja pokrajinskega vpliva neurejenih odlagališč odpadkov na kakovost podtalnice v prodnih sedimentih. Geografski vestnik 73-1.

Lidar 2008, () GEOIN/Geodetski inženiring, Maribor.

Mlekuž, D., 2010: Lidar in geoarheologija aluvialnih pokrajin. Geografski informacijski sistemi v Sloveniji 2009-2010. Ljubljana.

Pacina, J., Weiss, L., 2011: Georelief reconstruction and analysis based on historical

maps and aerial photographs. Symposium GIS Ostrava proceedings. Ostrava.

Podobnikar, T., Možina, P., 2008: Analiza oblik površja z uporabo lokalnega okna. Geografski informacijski sistemi v Sloveniji 2007-2008. Ljubljana.

Podobnikar, T., Schöner, M., Jansa, J., Pfeifer, N. 2008: Spatial analysis of anthropogenic impact on karst geomorphology (Slovenia). Environmental geology 58-2. DOI: http://dx.doi.org/10.1007/s00254-008-1607-3

Radinja, D. 1951: Sava na Ljubljanskem polju. Geografski vestnik 23.

Silvestri, S., Omri, M., 2008: A method for remote sensing identification of

uncontroled landfills: formulation and validation. International Journal of Remote Sensing 29, 3-4. DOI:

http://dx.doi.org/10.1080/01431160701311317

Smrekar, A., 2007: Divja odlagališča odpadkov na območju Ljubljane. Georitem 1. Ljubljana. 
Šebenik I., 1994: Pokrajinske značilnosti manjših neurejenih odlagališč odpadkov v Sloveniji. Geographica Slovenica 26-1.

Šifrer, M. 1969: Kvartarni razvoj Dobrav na Gorenjskem. Acta geographica 11.

Yoëli, P.,1965: Analytische Schattierung. Ein kartographischer Entwurf. Kartographische Nachrichten 15-5.

Zakšek, K., Kokalj, Ž., Oštir, K., 2010: Uporaba deleža vidnega neba za vizualizacijo reliefa. Geografski informacijski sistemi v Sloveniji 2009-2010. Ljubljana. 


\section{Odkrivanje prikritih odlagališč odpadkov v prodni ravnini z geomorfometrično analizo in LiDAR DMR}

DOI: http://dx.doi.org/10.3986/AGS54106

UDK: 911.2:551.43(497.451Lj. polje)

551.43:628.472.3(497.451Lj. polje)

628.472.3:528.8(497.451Lj. polje)

COBISS: 1.01

IZVLEČEK: V članku predstavljamo geomorfološki pristop za odkrivanje nekdanjih odlagališč odpadkov v prodni ravnini na primeru Ljubljanskega polja. Večina nekdanjih odlagališč odpadkov je skritih v vbočenih reliefnih oblikah: starih neaktivnih gramoznicah ali starih rečnih strugah (paleo struge). Z vizualno interpretacijo reliefa smo najprej določili antropogene reliefne oblike, ki so nastale zaradi izkopavanja proda in reliefne oblike, ki se izoblikujejo z odlaganjem odpadkov v kotanje. Uporabili smo LiDAR DMR, ki smo ga prikazali s pomočjo analitičnega senčenja in hipsometrične barvne lestvice. Ugotovili smo, da je zaradi posedanja heterogenih odpadkov, relief nekdanjih odlagališč v kotanjah, ki niso bila strokovno sanirana, grbinast in zato neznačilen za linijsko oblikovan fluvialni relief prodne ravnine. Na podlagi teh ugotovitev vizualne analize, smo s pomočjo dveh geomorfometričnih indeksov (konvergenčni indeks in indeks ploskosti) fluvialni relief prodne ravnine ločili v tri razrede: (1) grbinasti relief, značilen za potencialna prikrita odlagališča, (2) ravni relief značilen za dna starih strug ter (3) »agrarni« relief, značilen za intenzivno obdelana kmetijska zemljišča. S primerjavo rezultatov obeh metod smo 26 od 46 antropogenih reliefnih oblik, ki smo jih določili z vizualno analizo, potrdili tudi z geomorfometrično analizo. Le 8 od teh 26 objektov pa se ujema tudi z nekdanjimi gramoznicami, določenimi na arhivskih aeroposnetkih.

KLJUČNE BESEDE: uporabna geografija, odlagališče odpadkov, gramoznica, stara struga, vizualna interpretacija, tekstura, geomorfometrija, LiDAR, DMR, Ljubljansko polje.

Uredništvo je prejelo prispevek 14. januarja 2013.

NASLOV:

Dr. Mateja Breg Valjavec

Geografski inštitut Antona Melika

Znanstvenoraziskovalni center Slovenske akademije znanosti in umetnosti

Novi trg 2, SI - 1000 Ljubljana, Slovenija

E-pošta: mateja.breg@zrc-sazu.si 


\section{Uvod}

Glavna raziskovalna tema so nekdanja odlagališča odpadkov v kotanjah Ljubljanskega polja. To so podzemni objekti, za katere je značilna nepoznana in heterogena struktura starih odpadkov, s katerimi so zapolnjene vbočene reliefne oblike. Rezultati predhodnih domačih študij (Bricelj 1988; Šebenik 1994; Kušar 2001; Breg in Urbanc 2005, Breg s sodelavci 2007; Smrekar 2007 itd.) in primerljivih mednarodnih študij (Silvestri in Omri 2008) dokazujejo, da je bilo odlaganje odpadkov v preteklosti vezano večinoma na naravne (stare struge, vrtače) in antropogene kotanje (gramoznice). Skladno s tem bomo v raziskavi predstavili reliefne značilnosti z odpadki zapolnjenih kotanj (gramoznice in stare struge) ter možnosti za določanje le-teh na podlagi geomorfoloških značilnosti.

Glavni cilj raziskave je daljinsko zaznavanje nekdanjih odlagališč odpadkov, skritih pod površjem, s pomočjo analize LiDAR podatkov, ki temelji na geomorfoloških metodah in poznavanju geomorfologije obrečne prodne pokrajine. Kljub izjemni natančnosti in uporabnosti LiDAR podatkov pa lahko na LiDAR DMR določamo samo podzemna odlagališča, katerih posledice so vidne na zemeljskem površju in zato na DMR. To velja za odlagališča, ki niso bila prekrita (sanirana) z ustrezno debelo plastjo rodovitne zemljine, ki bi omogočala intenzivno kmetijsko obdelavo. Na tovrstnih odlagališčih zato ni prisotna intenzivna kmetijska raba tal ampak trajni travniki in zaraščanje, kar se odraža v mikro-reliefu oziroma teksturi prikazanega reliefa.

V preteklih študijah so poskušali zaznavati podzemna odlagališča $z$ uporabo različnih tehnik daljinskega zaznavanja predvsem $\mathrm{z}$ uporabo več-spektralnih satelitskih posnetkov. Poudarek je bil na zaznavanju degradiranih tal, s poudarkom na degradiranem rastlinstvu in prsti. Podrobnejši pregled daljinskega zaznavanja različnih tipov odlagališč odpadkov je na voljo v člankih Silvestrija in Omrija (2008) ter Sloneckerja s sodelavci (2010). Bistveno manj raziskav je bilo narejenih z vidika preučevanja reliefnih posledic, ki nastanejo zaradi odlaganja odpadkov. $\mathrm{V}$ ta namen so bili uporabljeni satelitski posnetki različnih prostorskih in spektralnih ločljivosti (Landsat TM, Landsat ETM, Quickbird, Ikonos, GeoEye1), kjer so z vizualno analizo določali geomorfološke spremembe, kot je dinamika prestavljanja rečnih strug, spreminjanje morske obale, meandrov in rekonstrukcija starih rečnih strug (Ghanavati s sodelavci 2008). Podobnikar s sodelavci (2008) ugotavlja, da analiza DMR s 25 m ločljivostjo celice omogoča tudi preučevanje večjih geomorfoloških sprememb, ki jih je povzročil človek: cestni nasipi, prometna, infrastruktura, zasute vrtače, aktivne gramoznice. Poseben pristop določanja antropogenih reliefnih sprememb je tudi določanje volumetričnih sprememb reliefa, ki jih kvantitativno določamo z iskanjem razlik med DMR-ji istega območja iz različnih obdobij. $S$ fotogrametrično metodo stereo-izvrednotenja arhivskih aeroposnetkov lahko prikažemo relief v nekdanji pokrajini. Relief nekdanje pokrajine primerjamo z reliefom današnje pokrajine in na tak način določimo višinske razlike in na primer zasute kotanje. Tovrsten način je bil uporabljen za določanje zasutih vrtač na Logaškem polju (Breg Valjavec 2010) ter v primeru površinskega kopa rudnika Bilina (Slovaška), kjer so na podoben način $\mathrm{z}$ volumetrično analizo določili količino izkopane rudnine $\mathrm{v}$ določenem obdobju (Pacina in Weiss 2011).

Ker so odlagališča, ki zapolnjujejo gramoznice, številna in po aluvialni pokrajini zelo razpršena, je geomorfometrična analiza reliefa prikritih odlagališč usmerjena v reliefne značilnosti manjših lokalnih območij. $\mathrm{Z}$ dostopnostjo visoko ločljivih LiDAR podatkov, razvojem digitalnih geomorfometričnih metod in posebne programske opreme je postalo možno tudi odkrivanje prikritih odlagališč z razpoznavanjem (mikro) reliefnih posledic. DMR, ki je izdelan iz laserskega oblaka točk, omogoča določanje najmanjših razlik v topografiji (od nekaj centimetrov do nekaj deset centimetrov), ki so posledica geomorfoloških ali antropogenih procesov. LiDAR omogoča opazovanje sledov človeškega delovanja iz različnih časovnih obdobij (plasti pokrajine), z njim razpoznavamo brazgotine in prstne odtise naravnih in antropogenih procesov na površini Zemlje (Komac 2009; Mlekuž 2010) ter odkrivamo teksturo »brazgotin«, ki so bile ustvarjene v naravnem reliefu zaradi podzemnega odlaganja odpadkov.

\section{Preučevano območje}

Ljubljansko polje je tektonska udorina zapolnjena predvsem s prodnimi in peščenimi sedimenti. V fluvialnem reliefu ob reki Savi so izoblikovane številne terase, višja pleistocenska in nižje holocenske (Radinja 1951; Šifrer 1969). S prestavljanjem rečnega toka iz starih v novo nastajajoče struge so predvsem na holocenskih 
terasah ohranjene stare opuščene struge. V pokrajini jih lahko opazujemo kot podolgovate rahlo vbočene reliefne oblike, še posebej v nižjih holocenskih terasah.

Študijsko območje (slika 4) predstavlja obmestno območje na severnem robu mesta Ljubljane s prevladujočo kmetijsko rabo tal (travniki in njive), ki prehaja $v$ mlado gozdno vegetacijo na prodiščih ob reki Savi. Območje je v neposredni bližini mesta, zato je zanj značilno, da je pod vplivom nezakonitega odlaganja odpadkov (Breg in Urbanc 2005). Zaradi prodnatih sedimentov, je Ljubljansko polje že od nekdaj zanimivo za pridobivanje gramoza, zlasti v bližini reke Save. Mnoge srednje velike gramoznice (od 1000 do $5000 \mathrm{~m}^{2}$ ), so bile v preteklosti delno ali v celoti zapolnjene $\mathrm{z}$ odpadki in so se spremenile $\mathrm{v}$ »odpadkovnice» (Breg in Urbanc 2009).

\section{Metodologija in LiDAR podatki}

S preučevanjem osnovnih geomorfoloških značilnosti naravnega reliefa prodne ravnine in določanjem značilnosti antropogenih reliefnih oblik smo postavili geomorfološki pristop za odkrivanje podzemno odloženih odpadkov in s tem nekdanjih odlagališč odpadkov. Uporabljen geomorfološki pristop, vključuje dva načina iskanja in preučevanja podzemnih odlagališč na DMR: (1) vizualna interpretacija reliefa in (2) geomorfometrična analiza. Pri tem smo upoštevali dejstvo, da $z$ uporabo in primerjavo več metod dosežemo večjo stopnjo natančnosti določitve reliefne oblike (Ciglič in Gostinčar 2011). Numerična, v tem primeru geomorfometrična analiza, kot tudi vizualna analiza DMR omogočata določanje naravnih reliefnih oblik in tudi antropogenih reliefnih oblik (Podobnikar in Možina 2008). Lokacije in reliefne značilnosti z odpadki zapolnjenih kotanj smo najprej določili z metodami vizualne interpretacije reliefa v nadaljevanju pa z geomorfometrično analizo in klasifikacijo fluvialnega reliefa. Uporabili smo LiDAR DMR (Lidar 2008 (C) GEOIN) izdelan na podlagi laserskega skeniranja površja $z$ dne 8. in 14. februarja 2008. Snemanje je potekalo z Optech Gemini LiDAR senzorjem. Primarna obdelava podatkov je bila opravljena z Dashmap 5.3 in programsko opremo PosPac 4.4. Za klasifikacijo in obdelavo podatkov je bil uporabljen programski paket Terra Solid in Microstation (Geoin 2011). Izmed štirih razredov klasificiranega oblaka točk, smo uporabili sloj relief, ki smo ga s predhodnimi obdelavami zgladili. Iz analize so bila izključena pozidana območja, ker na njih ni možno določati nekdanjih odlagališč.

\section{Vizualna interpretacija in značilnosti antropogenega reliefa odlagališ̌}

Reliefne anomalije, ki so predvidoma antropogenega nastanka, smo določali na LiDAR DMR, ki smo ga prikazali z različnimi tehnikami vizualizacije. Ne glede na širok spekter uporabe DMR, je prva stopnja njegove uporabe nazoren prikaz oziroma vizualizacija numeričnih podatkov o nadmorskih višinah. Kljub mnogim opisom naprednih prikazov reliefa, ostaja analitično senčenje ena najpogostejših metod (Zakšek s sodelavci 2010). Analitično senčenje (Slika 2 in 3) pomeni le računalniško podprto izdelavo senčenega reliefa iz DMR. Kot standard se je uveljavila metoda, ki jo je razvil Yoëli (1965) in pri kateri je vrednost sivine sorazmerna kosinusu vpadnega kota žarka neposredne osvetlitve reliefa. Gre za kot med smerjo proti viru svetlobe in pravokotnico na ploskev reliefa. Tako so območja pravokotna glede na žarek iz navideznega svetlobnega vira bela, območja $z$ vpadnim kotom osvetlitve $90^{\circ}$ ali več, pa so v popolni senci in so črna, medtem ko so območja $\mathrm{z}$ vpadnim kotom med $0^{\circ}$ in $90^{\circ}$ prikazana $\mathrm{z}$ ustreznim sivim ali drugim barvnim tonom (Zakšek s sodelavci 2010). Hipsometrija (Slika 1) je vizualizacijska tehnika, kjer prikažemo vrednosti DMR s hipsometrično barvno lestvico. Z raztezanjem ali krčenjem histograma slike prilagodimo prikaz potrebam analize. $V$ našem primeru je to izpostavljanje manjših reliefnih oblik oziroma značilnosti mikro-reliefa. Obe vizualizacijski tehniki, analitično senčenje in hipsometrija, smo uporabili na manjših izsekih podatkov LiDAR (velikost $750 \mathrm{~m} \times 500 \mathrm{~m}$ ) s čimer smo zmanjšali interval med najnižjo in najvišjo vrednostjo slike (nadmorsko višino) ter dosegli boljši barvni kontrast v prikazu reliefa ravnine in izrazitejšo osenčenje mikro-oblik (Slika 1, levo). S takšno metodologijo prikaza DMR smo zelo natančno rekonstruirali potek starih strug v agrarni pokrajini. Določili smo značilnosti fluvialnega reliefa prodne ravnine (suhe struge) in geomorfološko izoblikovanost območij z odpadki zapolnjenih kotanj. Za nadaljnjo geomorfometrično analizo je bistvena značilnost starih strug. Imajo obsežno longitudinalno ravno 
dno (naklon pod $0,5^{\circ}$ ) in hiter porast naklona v brežinah, kar omogoča tudi natančno geomorfometrično opredelitev starih rečnih strug. $Z$ vizualno interpretacijo smo odkrili izbočene anomalije $\mathrm{v}$ strugah, ki so posledica antropogenih aktivnosti in s tem potencialna odlagališča odpadkov. Prekinitve strug se pojavijo lokalno, kjer na določenem odseku strugo prekine izbočena oblika (kup odpadkov), struga pa se po prekinitvi nadaljuje (Slika 1). Kakovost vizualne interpretacije izbočenih antropogenih reliefnih oblik znotraj starih strug na LiDAR DMR je odvisna od velikosti vizualiziranega območja DMR. Na levi sliki je povečan pogled iz DMR velikosti $750 \times 500 \mathrm{~m}$ in na desni sliki povečan pogled v DMR celotnega območja.

Slika 1: Rekonstruiranje starih strug z vizualno analizo na različno velikih izsekih DMR in reliefne anomalije v strugi.

Glej angleški del prispevka.

$\mathrm{Z}$ odpadki zasute gramoznice $\mathrm{v}$ fluvialnem reliefu ravnine ne izstopajo izrazito, saj so bile $\mathrm{z}$ zasutjem izravnane z okoliškim reliefom. Ker so odpadki zelo heterogeni, razpadajo z različno intenzivnostjo in se tudi različno posedajo. Grbinast relief, ki se v desetletjih oblikuje nad odpadki, se razlikuje od fluvialnega reliefa v prodnati okolici (slika 2). Že latinsko ime (lat. Fluvio pomeni reko) pove, da so fluvialne reliefne oblike nastale zaradi toka vode. Širše gledano oblikuje fluvialni relief celotna hidrografska mreža, kjer se laminarni tokovi združujejo v linearnega in na koncu v reko. Naravne fluvialne oblike so, zaradi takšnega delovanja vode, linearnih oblik (dolina, grapa, soteska, erozijski jarek, sleme), medtem ko so grbinaste reliefne oblike, značilne za z odpadki zapolnjene gramoznice, nelinearne. Najbolje jih zaznamo z vizualno interpretacijo senčenega reliefa (Slika 2). Naravni fluvialni relief preučevane pokrajine je močno preoblikovan predvsem zaradi tradicionalne in intenzivne kmetijske rabe tal. Na visoko-ločljivih LiDAR DMR-jih lahko učinke različne rabe tal zaznamo in omogočajo klasifikacijo različnih tipov rabe tal. $V$ primeru z odpadki zapolnjenih kotanj imajo pomembno vlogo različno posedajoči se odpadki, ki predstavljajo antropogeno matično podlago.

Na podlagi vizualne analize reliefa ugotavljamo tudi, da pri izoblikovanju mikro-reliefnih oblik v povsem ravnem fluvialnem reliefu pogosto prevzamejo vodilno vlogo (pre)oblikovanja reliefa pokrajinske prvine kot je matična podlaga (tudi antropogena na primer odpadki), prst (globina prsti), rastlinstvo (drevesne korenine), živalstvo (delovanje krta) in navsezadnje človek (oranje). Skladno s tem smo odlagališčem podoben grbinast relief odkrili tudi v tipih rabe tal, kjer ni antropogenih vplivov:

- grbinast mikro-relief relief na pogozdenih prodiščih ob Savi, ki se izoblikuje zaradi delovanja korenin in zardi plitve rendzine;

- grbinast mikro-relief je značilen za opuščene kmetijske površine, znotraj intenzivnih kmetijskih zemljišč in je omejen na manjše pasove (na primer mejice) ali parcele;

- grbinast mikro-relief na pašniku ali trajnem travniku, kjer so prisotna drevesa (zeleni obroč na Sliki 3).

Dokončno razločevanje med opisanimi naravnimi grbinastimi mikro-reliefnimi oblikami ter antropogenimi grbinastimi oblikami, ki nastanejo na z odpadki zapolnjenih kotanjah, je možno z geo-historično analizo in določitvijo gramoznic v preteklosti (analiza arhivskih letalskih posnetkov), rekonstrukcijo starih strug in terenskim vzorčenjem (npr, prsti).

Slika 2: Relief z odpadki zapolnjene in samo zatravljene gramoznice je najpogosteje rahlo grbinast. Relief okoliških njiv pa je spremenjen zaradi oranja in rahljanja prsti.

Glej angleški del prispevka.

Slika 3: Izoblikovanost površja na trajnem travniku (območje omejeno zzeleno) je zelo podobno izoblikovanosti površja na z odpadki zapolnjeni zatravljeni gramoznici (glej sliko 2).

Glej angleški del prispevka.

Na vzorčnem območju (velikem $5 \mathrm{~km}^{2}$ ) smo z vizualno analizo DMR določili 67 antropogenih reliefnih oblik, ki se navezujejo na izkopavanje gramoza (gramoznice) in odlaganje odpadkov (Slika 4). Antropogene reliefne oblike smo razdelili v štiri skupine glede na vbočenost / izbočenost ter razgibanost reliefa (grbinast relief) (Slika 4):

1. Izbočene reliefne oblike, so potencialna odlagališča odpadkov, ki so nastala v prenapolnjeni gramoznici oziroma predstavljajo kup odpadkov dvignjen nad raven okoliškega površja.

2. Grbinaste reliefne oblike (potencialna odlagališča):

2A. grbinast (rahlo) izbočen mikro-relief,

2B. grbinast (rahlo) vbočen mikro-relief,

3. Vbočene reliefne oblike so domnevno opuščene gramoznice ali naravne stare struge; 
Pri izbočenih (5), grbinastih rahlo izbočenih (24) in grbinastih rahlo vbočenih (17) oblikah reliefa je sum, da so nastale zaradi odlaganja odpadkov v kotanje, največji, zato so njihove značilnosti pomembne kot osnova za nadaljnjo geomorfometrično analizo. Skladno s tem je rezultat vizualne analize 46 potencialnih odlagališč odpadkov v kotanjah.

Slika 4: Prostorska razporeditev antropogenih reliefnih oblik, ki smo jih določili z vizualno analizo LiDAR DMR na preučevanem območju Ljubljanskega polja.

Glej angleški del prispevka.

\section{Geomorfometrična analiza in rezultati}

Geomorfometrija je veda, ki se ukvarja s kvantitativnim preučevanjem reliefa; njen cilj je pridobivanje reliefnih parametrov in reliefnih oblik na podlagi digitalnih modelov reliefa (Hengl in Reuter 2009, Hrvatin in Perko 2009). Sodobna geomorfometrija se razlikuje od klasične kvantitativne geomorfologije po tem, da temelji povsem na računalniški analizi reliefa (Hengl in Reuter 2009). Geomorfometrična analiza je druga stopnja naše raziskave, s katero želimo avtomatsko določiti območja, ki imajo reliefne značilnosti z odpadki zasutih kotanj.

Digitalni model reliefa lahko razdelimo v razrede $\mathrm{z}$ uporabo geomorfometričnih parametrov kot je naklon in ukrivljenost reliefa. Za natančnejšo klasifikacijo geomorfoloških oblik uporabimo dodatne parametre, kot je na primer akumulacija vodnega toka za določanje reliefnih oblik povezanih s fluvialnimi procesi (Anders s sodelavci 2009). Z izračunom konvergenčnega indeksa reliefa (Index of convergence) smo izločili uravnana konvergentna območja, saj niso značilna za že predstavljeni relief z odpadki zasutih kotanj pač pa označujejo naravne vbočene reliefne oblike (stare struge) in nezasute gramoznice. Modul je vgrajen v program SAGA in izračunava indeks površinskega stekanja / raztekanja vode. Po pomenu je podoben planarni ali horizontalni ukrivljenosti reliefa (curvature), a daje veliko boljše rezultate. Izračun temelji na celicah v okolici, t. j. preuči, do katere stopinje celice v okolici so usmerjene na sredinsko celico. Rezultat je predstavljen v odstotkih, kjer negativne vrednosti ustrezajo stekanju, pozitivne vrednosti pa odtekanju vodnega toka. Območja ravnega reliefa smo od neravnega (valovitega, grbastega) ločili z indeksom ploskosti reliefa (ang. multiresolution index of valley bottom flateness - MrVBF). Slednji se izračuna s samostojnim modulom v programu SAGA, namenjen pa je kartiranju sedimentacijskih območij ( $v$ našem primeru stare struge). Algoritem za izračun indeksa ploskosti (Gallant in Dowling, 2003) deluje, kot konvergenčni indeks, na rastrskih DMR. Ploskost doline (ang. valley bottom flateness, $V F$ ) je izračunana kot funkcija lokalne topografske lege v celici znotraj premikajoče se sence in pobočja v $3 \times 3$ oknu celice. Celica je del ravne doline, ki je lokalno ploska in ima nizko pobočje. Približne vrednosti za več ločljivosti so izračunane tako, da ponovno vzorčimo DMR na vedno bolj slabe ločljivosti in pri tem ponavljamo postopek. Indeks ploskosti je tako izmerjena kombinacija posameznih vrednosti VF, kjer so vrednosti VF, ki so manjše od 0,5, določene kot grebeni in so zato izločene (Gallant in Dowling 2003).

Na podlagi rezultatov opisanih geomorfometričnih indeksov (sloj 1, sloj 2) smo relief aluvialne ravnine razdelili v tri razrede (preglednica 1, slika 5). Razred 3 predstavlja relief značilen za dna starih suhih strug (povsem raven relief). V razred 2 spada antropogeno spremenjen raven agrarni relief, ki je posledica kmetijskega obdelovanja in je značilen za njive in intenzivne travnike. Za razred 1 je značilen grbinast, rahlo valovit relief, ki se pojavlja na odlagališčih odpadkov a tudi na povsem naravnih območjih kot je

Preglednica 1: Postopek združevanja rezultatov obeh geomorfometričnih indeksov.

\begin{tabular}{ccccc}
\hline sloj & ime sloja & vrednost celice & vrednost celice & Sloj 1+2 \\
\hline sloj 1 & $\begin{array}{c}\text { konvergenčni } \\
\text { indeks }\end{array}$ & $\begin{array}{c}\text { 0 (območje stekanja } \\
\text { vode - vbočen relief) }\end{array}$ & $\begin{array}{c}1 \text { (območje raztekanja } \\
\text { vode - izbočen relief) }\end{array}$ & RAZRED 2 \\
\hline sloj 2 & indeks ploskosti & 0 (raven relief) & $\begin{array}{c}1 \text { (neraven, } \\
\text { grbinast relief) }\end{array}$ & $\begin{array}{c}\text { 1 (uravnan antropogeno } \\
\text { spremenjen relief) }\end{array}$ \\
\hline
\end{tabular}


gozd, trajni travnik in podobnih neintenzivnih tipih rabe tal, kot je bilo navedeno že tudi pri rezultatih vizualne analize v prejšnjem poglavju. Območja znotraj razreda 1 smo poimenovali območja z visokim reliefnim potencialom za nekdanje odlagališče odpadkov.

Slika 5: Geomorfometrična klasifikacija ravninskega reliefa.

Glej angleški del prispevka.

\section{Razprava in sklepi}

Na podlagi rezultatov ugotavljamo, da sta za določanje z odpadki zapolnjenih kotanj uporabni obe predstavljeni metodi vizualne interpretacije reliefa. Vendarle pa je za uspešno določanje popolnoma zasutih gramoznic primernejši prikaz DMR z analitičnim senčenjem reliefa, pri čemer je, zaradi majhnih reliefnih razlik med zasuto kotanjo in okolico, pomemben pokazatelj tekstura senčenega reliefa. Na senčenem reliefu smo odkrili grbinast relief zasutih kotanj, ki ga na nesenčenem reliefu težje zaznamo ali sploh ne zaznamo. Za določanje odlagališč $\mathrm{v}$ starih strugah je primernejši prikaz reliefa s hipsometrično barvno lestvico, saj so pokazatelj reliefne razlike, ki jih lahko zaznamo $\mathrm{z}$ vizualno interpretacijo.

Z združevanjem in prekrivanjem rezultatov vizualne (Slika 4) in geomorfometrične analize (Slika 5), ki so predstavljeni na Sliki 6, ugotavljamo, da se 26 od skupno 46 vizualno razpoznanih antropogenih reliefnih oblik, ki so potencialna odlagališča odpadkov, pokriva z območji visokega reliefnega potenciala za nekdanja odlagališča odpadkov (Razred 1). Te antropogene reliefne oblike lahko z veliko gotovostjo opredelimo kot potencialna odlagališča odpadkov. Za dodatno potrditev rezultatov LiDAR analize smo uporabili geohistorične podatke o starih gramoznicah (Breg Valjavec, Gostinčar in Smrekar 2011), kjer je prostorsko lociranih 30 gramoznic v različni stopnji izkopavanja gramoza v presečnih letih 1959, 1964, 1975, 1985 in 1994.

Slika 6: Primerjava rezultatov obeh metod (vizualne in geomorfometrične analize) in delna potrditev rezultatov z geohistoričnimi podatki o gramoznicah (Breg Valjavec, Gostinčar in Smrekar 2011).

Glej angleški del prispevka.

LiDAR podatki, ki so za računalniško modeliranje še vedno zelo zahtevni (količinsko obsežni), so še vedno najlažje obvladljivi z uporabo najrazličnejših vizualizacijskih tehnik (Kalawsky 2009 v: Mlekuž 2010). Slednje so uporabne tudi kadar preučujemo manjša ravninska območja. Nedvomno pa je veliko možnosti za odkrivanje nekdanjih odlagališč odpadkov tudi v sodobnih in prihodnjih geomorfometričnih analizah LiDAR reliefa. Uspeh pri odkrivanju odlagališč odpadkov z geomorfometrijo pa je najbolj odvisen od vrste odlagališča, njegovih reliefnih in mikro-reliefnih značilnosti ter rabe tal nad odloženimi odpadki. Opisana geomorfometrična analiza je uporabna za določanje izbočenih reliefnih oblik ter grbinastih (rahlo izbočenih) mikro-reliefnih oblik, ki so hkrati potencialna odlagališča odpadkov. Na Sliki 6 so slednja označena $\mathrm{z}$ rdeče obrobljenimi prozornimi poligoni, ki prekrivajo sivo in sivo-modro črtkano območje. Vbočene in grbinaste (rahlo vbočene) reliefne oblike (na sliki 6 označene z črno obrobljenimi belimi poligoni), ki so potencialno tudi odlagališča odpadkov, z opisano geomorfometrično analizo niso določljive. Predstavljajo bodisi opuščene gramoznice, delno zapolnjene gramoznice ali stare struge. Če želimo iz teh oblik izločiti potencialna odlagališča odpadkov, je potrebna dodatna geohistorična analiza in terensko delo.

Predstavljena geomorfometrična analiza omogoča najboljše rezultate v kmetijski pokrajini s prevladujočo kmetijsko rabo tal (njive, travniki) kakor tudi na odprtih površinah brez vidnejšega rastlinskega pokrova (brez dreves). Nasprotno pa je metodologija skoraj neuporabna na z drevesih poraslih območjih znotraj kmetijskih zemljišč in $\mathrm{v}$ gozdu saj imajo podobne mikro-reliefne značilnosti kot $\mathrm{z}$ odpadki zapolnjene gramoznice. Če želimo na teh območjih ločiti območja antropogenih grbinastih oblik, torej potencialna odlagališča, od naravnega grbinastega reliefa, je potrebna dopolnilna analiza rastlinskega pokrova oziroma analiza gostote in višine dreves. Uporabimo lahko letalske ali satelitske posnetke (npr. infrardeč sloj) $\mathrm{v}$ kombinaciji z LiDAR slojem vegetacije. Na podlagi rezultatov terenskega preučevanja rastlinstva na nekdanjih odlagališčih odpadkov (Breg Valjavec 2012) predpostavljamo, da visoka in gosto zasajena drevesa uspevajo na stabilni naravni matični podlagi in prsti, ki omogočata oporo visokoraslim rastlinam. Na površini odlagališč (npr. odlagališče v zapolnjeni gramoznici), ki so znotraj gozda pa so drevesa redkejša, nižja 
in grmovne rasti saj antropogena matična podlaga (nesprijeti, heterogeni odpadki) in antropogena prst (deposol) ne omogočata stabilne in kakovostne rasti gostim in visokim drevesom (npr. hrast dob).

S prihodnjimi raziskavami je potrebno metodologijo izboljšati v okviru obstoječih geomorfometričnih metod, GIS modeliranja reliefa, z vpeljavo dodatnih visoko-ločljivih podatkov (raba tal, satelitski posnetki) ter z bolj objektno usmerjeno geomorfometrično analizo. Samo z opisano geomorfometrično analizo, brez vizualne analize, lahko določamo samo širša območja, ki imajo reliefne značilnosti, ki so podobne reliefu z odpadki zasutih kotanj, ne pa natančne lege in oblike posameznega odlagališča v kotanji oziroma kotanje. Upoštevajoč geomorfološka izhodišča, na katerih temelji predstavljeni koncept odkrivanja prikritih, podzemnih odlagališč, je metodologija uporabna $\mathrm{v}$ preučevanju odlagališč v podobnih aluvialnih obrečnih ravninah (npr. prodnih, ilovnatih), kjer jih je možno postaviti v kontekst starih suhih strug na poplavnih ravnicah.

\section{Literatura}

Glej angleški del prispevka. 